\title{
Aphid performance changes with plant defense mediated by Cucumber mosaic virus titer
}

\author{
Xiaobin Shi', Yang Gao', Shuo Yan ${ }^{1}$, Xin Tang ${ }^{1}$, Xuguo Zhou'², Deyong Zhang ${ }^{1,3^{*}}$ and Yong Liu ${ }^{1,3^{*}}$
}

\begin{abstract}
Background: Cucumber mosaic virus (CMV) causes appreciable losses in vegetables, ornamentals and agricultural crops. The green peach aphid, Myzus persicae Sulzer (Aphididae) is one of the most efficient vectors for CMV. The transmission ecology of aphid-vectored CMV has been well investigated. However, the detailed description of the dynamic change in the plant-CMV-aphid interaction associated with plant defense and virus epidemics is not well known.

Results: In this report, we investigated the relationship of virus titer with plant defense of salicylic acid (SA) and jasmonic acid (JA) during the different infection time and their interaction with aphids in CMV-infected tobacco plants. Our results showed that aphid performance changed with virus titer and plant defense on CMV-inoculated plants. At first, plant defense was low and aphid number increased gradually. The plant defense of SA signaling pathway was induced when virus titer was at a high level, and aphid performance was correspondingly reduced. Additionally, the winged aphids were increased.
\end{abstract}

Conclusion: Our results showed that aphid performance was reduced due to the induced plant defense mediated by Cucumber mosaic virus titer. Additionally, some wingless aphids became to winged aphids. In this way CMV could be transmitted with the migration of winged aphids. We should take measures to prevent aphids in the early stage of their occurrence in the field to prevent virus outbreak.

Keywords: Cucumber mosaic virus, Myzus persicae, Plant defense, Jasmonic acid, Salicylic acid

\section{Background}

Plants are constantly attacked by many kinds of plant viruses, and they have evolved extraordinarily complex mechanisms to defend themselves [1]. About $80 \%$ plant viruses depend on insect vectors for transmission [2,3]. At present, the triple plant-virus-vector interaction has been paid more and more attention for understanding the complex interplay of factors resulting in virus emergence. In the current study, we investigate the triple interactions between Cucumber mosaic virus (CMV), Myzus persicae Sulzer (Aphididae), and tobacco plants.

\footnotetext{
* Correspondence: dyzhang78@163.com; haoasliu@163.com

${ }^{1}$ Key Laboratory of Integrated Management of the Pests and Diseases on Horticultural Crops in Hunan Province, Hunan Plant Protection Institute, Hunan Academy of Agricultural Sciences, Changsha 410125, China

32Longping Branch, Graduate College, Hunan University, Changsha 410125, China

Full list of author information is available at the end of the article
}

Cucumber mosaic virus (CMV) causes appreciable losses in vegetables, ornamentals and agricultural crops $[4,5]$. CMV has a broad host range, including more than 1,200 plant species in over 100 families [6]. CMV is transmitted by 80 species of aphids in 33 genera in a non-persistent manner [5]. The green peach aphid, $M$. persicae is one of the most efficient vectors for CMV [7], and is frequently used in transmission experiments [8].

Plants can antagonize the growth, development and preference of insect vectors directly and therefore affect virus transmission indirectly. The plant-vector interaction appears favorable to the persistent transmission, such as those described for Barley yellow dwarf virus (BYDV) and Potato leaf roll virus (PLRV), that both attract vectors to and encourage their population growth and sustained feeding on infected plants $[9,10]$. Our previous results also showed that infection of Tomato yellow leaf curl virus (TYLCV) 
increased the performance of whiteflies, Bemisia tabaci to facilitate virus transmission [11-13]. Previous research, however, revealed the different pattern of plant-vector interaction for transmission of nonpersistent viruses from that of the transmission of persistent viruses [14]. CMV-infected squash plants are poor hosts for aphid vectors, while aphids exhibited a preference for the elevated volatile emissions of infected plants. Besides, CMV infection induces changes in host palatability and quality for aphid vectors rapid dispersal following virus acquisition $[15,16]$. The transmission ecology of aphid-vectored CMV has been well investigated, and interactions between viruses and aphids are key factors influencing CMV epidemics [17]. However, the detailed description of the dynamic change in the plant-CMV-aphid interaction associated with plant defense and virus epidemics was not well known.

The signaling pathways in this plant-CMV-aphid interaction influence each other through a complex network of synergistic and antagonistic interactions [18]. The phytohormones salicylic acid (SA) and jasmonic acid (JA) are known to participate in defense responses in plants [19-21]. There is considerable cross-talk between JA and SA [22-25]. In plant-insect interactions, SA induction has been confirmed to be an effective defense response against aphids and whiteflies [26, 27]. $\beta-1,3$-glucanases is an important pathogenesis-related (PR) protein in response to pathogenic infection mediated by SA (Livne [28]; Chen [29]). Protease inhibitor is caused by JA as a result of injury (Turner [30] Zhang et al. [31]).

In the process of virus infection, whether the virus titer has a time effect on plant defense such as JA and SA in molecular and biochemical level which can regulate aphid performance is largely unknown. In this report, we investigated the relationship of virus titer with SA and JA during the different infection time and their interaction with virus vector aphids in CMV-infected tobacco plants. Our goal was to find some ecological mechanisms in the virus epidemics of CMV.

\section{Methods}

\section{Plant, aphid colonies and virus culture}

Tobacco plants (Nicotiana tabacum cv. Samsum) were grown in a potting mix (a mixture of vermiculite, peat moss, organic fertilizer and perlite in a 10:10:10:1 ratio by volume) in insect-free cages $(60 \times 60 \times 60 \mathrm{~cm})$ in a glasshouse. Myzus persicae (Sulzer) were raised in colonies on tobacco plants. When plants were at the 3-4 true leaf stage, they were inoculated with $5 \mathrm{~cm}^{2}$ of frozen stock tissue infected with $\mathrm{CMV}$ (stored at $-80{ }^{\circ} \mathrm{C}$ ). Frozen tissue was ground with $5 \mathrm{ml}$ of $0.1 \mathrm{M}$ potassium phosphate buffer on a cold surface. Carborundum powder was then added and the mixture was applied to surfaces of tobacco leaves using cotton swabs. Control plants were mock-inoculated in the same manner, but with healthy tobacco tissue.

\section{Viral load with DAS-ELISA}

Virus titer was determined after 3, 6, 9, 12 and 15 days of CMV-inoculation. The identity of the virus titer was detected though DAS-ELISA using diagnostic kit (ADGEN, UK).

\section{JA and SA in molecular and biochemical level}

The gene expression of the JA and SA signaling pathway in CMV-inoculated plants were determined at 3, 9 and 15 days post-inoculation. The JA upstream gene OPR3 and downstream genes COI1 and PDF1.2 were measured. At the same time the SA upstream gene ICS1 and downstream genes NPR1 and PR1 were measured. Actin was used as the internal reference gene [32]. Total RNA was extracted from $0.2 \mathrm{~g}$ of CMV-inoculated leaves, and $1.0 \mu \mathrm{g}$ of RNA was used to synthesize the first-strand cDNA using the PrimeScript ${ }^{\circ}$ RT reagent Kit (Takara Bio, Tokyo, Japan) with gDNA Eraser (Perfect Real Time, TaKara, Shiga, Japan). The $25.0 \mu \mathrm{l}$ reaction system containing $10.5 \mu \mathrm{l}$ of $\mathrm{ddH}_{2} \mathrm{O}, 1.0 \mu \mathrm{l}$ of cDNA, $12.5 \mu \mathrm{l}$ of SYBR $^{\circ}$ Green PCR Master Mix (TIANGEN, Beijing, China), and $0.5 \mu \mathrm{l}$ of each primer (Table 1). Relative quantities of RNA were calculated using the comparative cycle threshold (Ct) (2- $\Delta \Delta \mathrm{Ct})$ method [33]. Three biological replicates and four technical replicates were analyzed.

The activity of proteinase inhibitor (PI) and $\beta-1,3-$ glucanases (GUS) of CMV-inoculated leaves were determined at 3, 9 and 15 days post-inoculation. The activity of PI was determined using standard protocol [12]. The activity of GUS was determined using standard protocol [34]. GUS activity was calculated as nmoles of MU per

Table 1 Primer sequences used for qPCR analysis

\begin{tabular}{|c|c|c|}
\hline Gene & GeneBank accession no. & Primer sequence \\
\hline OPR3 & EF467331 & $\begin{array}{l}\text { F: 5'- AGGCACTATGATTTCTC-3' } \\
\text { R: 5'- GTTGATCCCATCTTTC-3' }\end{array}$ \\
\hline COl1 & AY547493 & $\begin{array}{l}\text { F: 5'- CACTTGATAATGGTGT-3' } \\
\text { R: 5'- AGGCCTTCATCGGATTCC-3' }\end{array}$ \\
\hline PDF1.2 & X99403 & $\begin{array}{l}\text { F: 5'- AACTTGTGAGTCCCAGAG-3' } \\
\text { R: 5'- GGATACCTTTCTACCACC-3' }\end{array}$ \\
\hline ICSI & DQ149918 & $\begin{array}{l}\text { F: 5'- TTAAACTCATCATCTTCAG-3' } \\
\text { R: 5'- GGCTTCGCCGGCATTCATT-3' }\end{array}$ \\
\hline NPR1 & AF480488 & $\begin{array}{l}\text { F: 5'- GCTGTGGCATTCCTGGTT-3' } \\
\text { R: 5'- GTGAGCCTCTTGGCGATT-3' }\end{array}$ \\
\hline PR1 & JN247448 & $\begin{array}{l}\text { F: 5'- TGCCTTCATTTCTTCTTG-3' } \\
\text { R: 5'- TTAGTATGGACTITCGCCTCT-3' }\end{array}$ \\
\hline Actin & AY179605 & $\begin{array}{l}\text { F: 5'- AACTGATGAAGATACTCACA-3' } \\
\text { R: 5'- CAGGATACGGGGAGCTAAT-3' }\end{array}$ \\
\hline
\end{tabular}


minute per milligram of protein. Three biological replicates and three technical replicates were analyzed.

\section{Aphid performance}

Vaseline was plastered at the culm of the tobacco to prevent aphids from escaping. After a $4 \mathrm{~h}$ equilibration period, 20 apterous adults of the same age, which had been starved for $4 \mathrm{~h}$, were placed separately on mockinoculated and CMV-infected tobacco plants. The mock-inoculated and CMV-infected tobacco plants with aphids were placed separately in insect-free cages $(40 \times$ $20 \times 40 \mathrm{~cm})$.

After 3, 6, 9, 12 and 15 days, the number of apterous and alate aphids on mock-inoculated and CMV-infected plants were count and recorded. In order not to miss any aphids, all the spaces in the cages were also checked. After each count, winged aphids were all removed by an aspirator, in order not to interfere the observation in the next time. Each experiment was repeated eight times.

To determine the longevity, aphids was collected and transferred to mock-inoculated and CMV-infected tobacco plants. Each plant was placed 20 apterous adults of the same age. The new born aphids were removed and every female was checked every day until their death, and the longevity of aphids was recorded.

\section{Statistical analysis}

One-way ANOVA was used to compare viral titer of CMV-infected leaves and to compare relative gene expression and enzyme activity of JA and SA signaling pathway. One-way ANOVA was also used to compare number of winged aphids on CMV-infected plants. Repeated-measures ANOVAs were used to compare the number of aphids on mock-inoculated plants and CMVinfected plants. Longevity of aphids on mock-inoculated plants and CMV-infected plants were compared with $t$ tests.

\section{Results}

Viral load with DAS-ELISA

Viral load differed significantly in the first 15 days $(F=$ 17.462, $P<0.001)$. Virus titer grew continuously at the beginning, and then, from the $9^{\text {th }}$ day, virus titer remained at a relatively stable level (Fig. 1).

\section{$J A$ and SA in molecular and biochemical level}

The expression of the JA upstream gene OPR3 was increased, and the expression of the JA downstream genes COI1 and PDF1.2 was decreased. Besides, the expression of COI1 and PDF1.2 was number numerically lowest on the $9^{\text {th }}$ day (Fig. 2a). The expression of SA upstream gene ICS1 and downstream genes NPR1 and PR1 was increased on CMV-inoculated plants. The SA-responsive

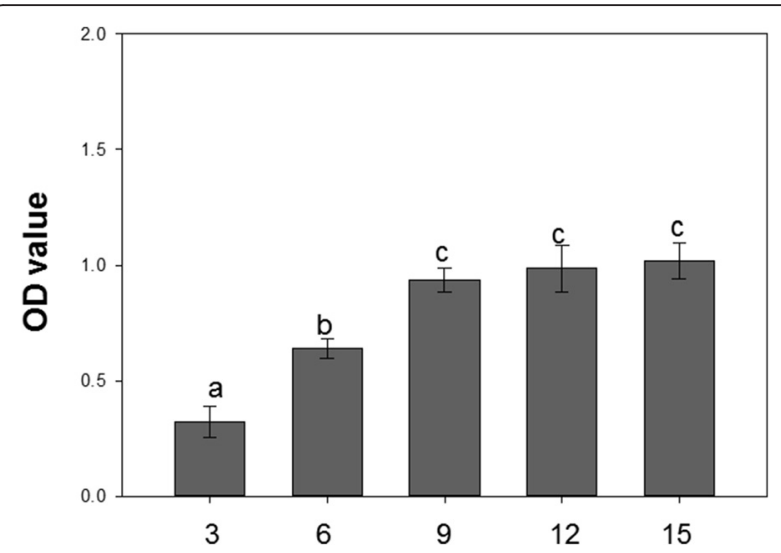

Fig. 1 Viral load with DAS-ELISA. The virus was Cucumber mosaic virus (CMV). Virus titer was determined after 3, 6, 9, 12 and 15 days of CMV-inoculation. Values are means \pm SE. Different letters indicate significant differences $(P<0.05)$

gene expression was numerically highest on the $9^{\text {th }}$ day (Fig. 2b).

PI activity was reduced from 3 days to 15 days and was numerically lowest on the $9^{\text {th }}$ day (one-way ANOVA: $F=$ 15.023, $P=0.005$, Fig. 2c). GUS activity was increased from 3 days to 15 days and was numerically highest on the $9^{\text {th }}$ day (one-way ANOVA: $F=15.902, P=0.004$, Fig. 2d).

\section{Aphid performance}

On the third day, aphid number was similar on CMVinfected plants and mock-inoculated plants. From the $6^{\text {th }}$ day to the $15^{\text {th }}$ day, there was significant difference in aphid numbers between individuals on CMV-infected plants and mock-inoculated plants (repeated-measurement ANOVA: $F=2739.310, P<0.001)$. Aphid growth rate on mock-inoculated plants only changed a little. However, aphid growth rate on CMV-infected plants slowed down gradually (Fig. 3a). The longevity of aphid on CMV-infected plants was significantly lower than on mock-inoculated plants $(F=0.293, P=0.005$; Fig. 3b). The number of winged aphids increased on CMVinfected plants from the $9^{\text {th }}$ day, and the number of winged aphids was highest on CMV-infected plants on the $15^{\text {th }}$ day (Fig. 3c).

\section{Discussion}

Our results demonstrate that there is a clear link between the aphid number, virus titer and plant defense. The number of aphids on virus-infected plants significantly increased in the beginning, but the number declined significantly after the virus titer maintained a certain level. Besides, the longevity of aphids on CMVinfected plants was lower than that on mock-inoculated plants. Our results show that in the early infection of CMV, infected plants can promote the growth and 

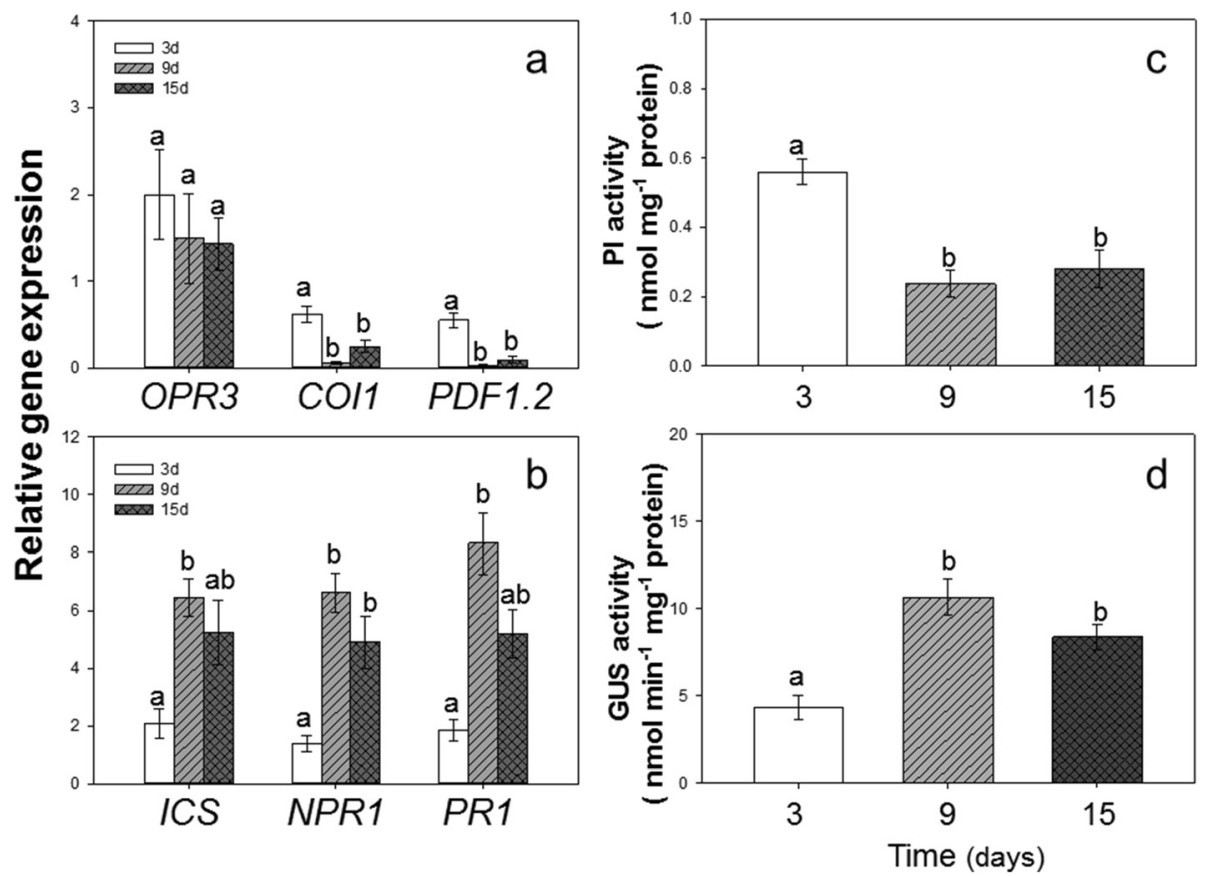

Fig. $2 \mathrm{JA}$ and SA in molecular and biochemical level. Gene expression levels and enzyme activities were determined on CMV-inoculated plants after 3, 9 and 15 days. a Gene expression levels of JA upstream gene OPR3 and downstream genes CO/1 and PDF1.2. b Gene expression levels of SA upstream gene ICS and downstream genes NPR1 and PR1. c Proteinase inhibitor (PI) activity. $\mathbf{d}$ $\beta$-1, 3-glucanases (GUS) activity. Values are means \pm SE. Within each panel, different letters indicate significant differences $(P<0.05)$

development of aphids. However, when the viral titer remained stable in plants, the growth of aphid was decreased. One previous result showed that survival of $M$. persicae was lower on CMV-infected tobacco, as compared to mock-inoculated plants within 14 days [35]. Another previous result showed that performance of $M$. persicae was dramatically reduced on CMV-infected plants within 15 days [14]. Combined with our results, we can find that aphid performance on CMV-infected plants is time-dependent.

Our results also showed that plant defense changed with the increase of virus titer. In the initial stages of CMV infection, only the expression of JA upstream gene OPR3 was induced to a higher level. However, the SA- relative genes were induced a little. On the $9^{\text {th }}$ day when the viral titer was highest, the expression of SAresponsive genes such as NPR1 was highest, and the expression of JA downstream genes was lowest. NPR1 has been reported to play a key role in the regulation of SA and JA antagonism [36]. For example, the infection of necrotrophic fungus Botrytis cinerea activates SA signaling via a tomato NPR1 homolog to exploit the antagonistic crosstalk between SA and JA signaling [37]. The 2b protein of CMV targets NPR1 to exploit SA-JA antagonism $[38,39]$. Our previous also showed that infection of TYLCV induced the NPR1 expression and reduced the JA downstream gene expression [12, 27]. Here we found that the NPR1 and PR1 both were induced by CMV
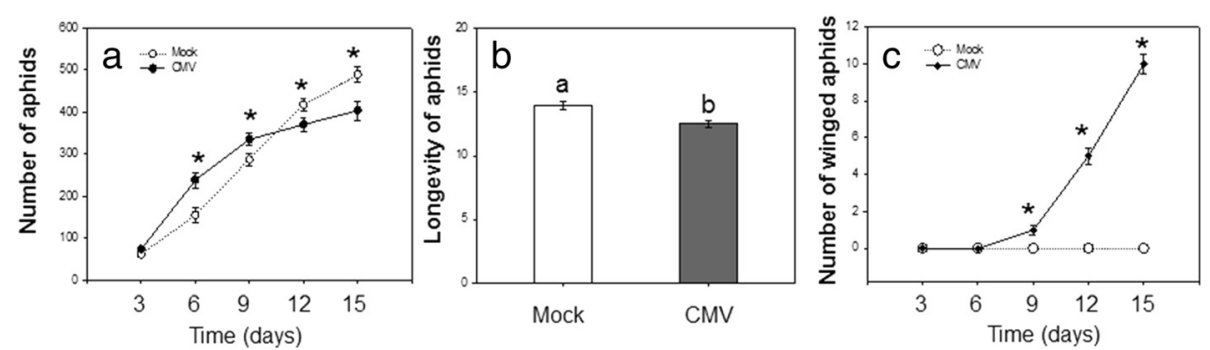

Fig. 3 Aphid performance on CMV-inoculated and mock-inoculated plants. a Aphid number. b Aphid longevity. c Number of winged aphids on CMV-inoculated plants. The virus was Cucumber mosaic virus (CMV). CMV: CMV-inoculated plants. Mock: mock-inoculated plants. Values are means \pm SE. Asterisks indicate significant differences $(P<0.05$, a). Different letters indicate significant differences $(P<0.05, \mathbf{b}$ and $\mathbf{c})$ 
infection and they play important roles in the antagonistic crosstalk between the SA and JA pathways. Therefore, CMV infection induced SA-regulated gene expression and disrupted JA-regulated gene expression, which is consistent with previous results [15, 35].

Proteinase inhibitor plays an important role in resisting insect herbivores and has been reported to be related with JA [31]. $\beta-1,3$-glucanases is also an important enzyme that is involved in response to salicylic acid (SA) [40]. In our results PI activity was reduced while GUS activity was increased, which is consistent with the expression change of JA and SA relative genes.

According to our results, compared with the mockinoculated plants, plant defense on CMV-infected plants in its early stage was low, and the aphid number increased rapidly. However, when the viral titer remained stable in plants, plant defense especially SAresponsive genes were induced to a higher level. SA can have neutral or negative effects on the growth of aphids [41]. Avila et al. [42] showed that FAD7 enhances plant defenses against aphids that are mediated through SA and NPR1. SA induction has been confirmed to be an effective chemical defense response against aphids [26]. In our research SA were induced by the increase of virus titer and therefore the growth of aphid was decreased.

Another possibility to consider is that plant quality is changed by infection of CMV. Previous research showed that CMV infection reduces the host palatability and quality, and the phloem sap quality is also reduced [15]. Combined with our results, it can be found that with the increase of viral titer, aphid performance can be reduced due to the reduction of plant physiology and morphology.

We also found that number of winged aphids increased with the increase of viral titer. Many factors, such as environmental conditions, aphid density and host plant quality, may influence wing production [43]. For example, a decrease in plant quality can trigger wing induction in some aphid species [44]. Here, we show that winged $M$. persicae on virus-infected leaves are more than on mock-inoculated leaves after 9 days, although the number of aphids on virus-infected leaves is lower than on mock-inoculated leaves. Therefore, we consider it unlikely that our result is caused by aphid density. The possible explanation is that plant defense is induced by CMV infection therefore plant quality is changed, which is consistent with previous results that plant quality decreases under infection of non-persistent viruses to promote aphid migration [45]. In our results we found that plant quality decreases under infection of non-persistent viruses and then the wingless aphids become to winged aphids.

\section{Conclusions}

We find some ecological mechanisms in the virus epidemics of CMV. The aphid performance changed with virus titer and plant defense on CMV-inoculated plants. At first, plant defense was low and aphid number increased gradually. The plant defense of SA signaling pathway was induced when virus titer was at a high level, and aphid performance was correspondingly reduced. Additionally, the wingless aphids became to winged aphids. CMV could be transmitted with the migration of winged aphids. We should take measures to prevent aphids in the early stage of their occurrence in the field to prevent virus outbreak. The physiological, biochemical and molecular mechanisms of wing production need to be further investigated.

Competing interests

The authors declare that they have no competing interests.

\section{Authors' contributions}

XBS, DYZ and YL designed the experiment. XBS, SY and XT carried the experimental work. YG and XGZ contributed reagents/materials. XBS wrote the paper. All authors read and approved the final manuscript.

\section{Acknowledgments}

This work was supported by the Special Fund for Agro-scientific Research in the Public Interest (no. 201303028), the Agriculture Research System of China (CARS-25-B-05) and the national natural science foundation of china (no. 31571982).

\section{Author details}

${ }^{1}$ Key Laboratory of Integrated Management of the Pests and Diseases on Horticultural Crops in Hunan Province, Hunan Plant Protection Institute, Hunan Academy of Agricultural Sciences, Changsha 410125, China. ${ }^{2}$ Department of Entomology, University of Kentucky, Lexington, KY 40546, USA. ${ }^{3}$ Longping Branch, Graduate College, Hunan University, Changsha 410125, China.

Received: 14 January 2016 Accepted: 10 April 2016

Published online: 22 April 2016

References

1. Dang JL, Jones JD. Plant pathogens and integrated defence responses to infection. Nature. 2001;411:826-33.

2. Hohn T. Plant virus transmission from the insect point of view. Proc Natl Acad Sci U S A. 2007;104:17905-6.

3. Andret-Link P, Fuchs M. Transmission specificity of plant viruses by vectors. J Plant Pathol. 2005;87:153-65.

4. Palukaitis P, Roossinck MJ, Dietzgen RG, Francki RI. Cucumber mosaic virus. Adv Virus Res. 1992:41:281-348.

5. Palukaitis P, García-Arenal F. Cucumoviruses. Adv Virus Res. 2003;62:241-323.

6. Pinto ZV, Rezende JAM, Yuki VA, Piedade SMS. Ability of Aphis gossypii and Myzus persicae to transmit Cucumber mosaic virus in single and mixed infection with two potyviruses to zucchini squash. Summa Phytopathol. 2008;34:183-5.

7. Hily JM, García A, Moreno A, Plaza M, Wilkinson MD, Fereres A, et al. The relationship between host lifespan and pathogen reservoir potential: an analysis in the system Arabidopsis thaliana-Cucumber mosaic virus. PLoS Pathog. 2014;10:e1004492.

8. Ali A, Li HY, Schneider WL, Sherman DJ, Gray S, Smith D, et al. Analysis of genetic bottlenecks during horizontal transmission of Cucumber mosaic virus. J Virol. 2006;80:8345-50.

9. Montllor CB, Gildow FE. Feeding responses of two grain aphids to Barley yellow dwarf virus-infected oats. Entomol Exp Appl. 1986;42:63-9.

10. Sylvester ES. Circulative and propagative virus transmission by aphids. Annu Rev Entomol. 1980;25:257-86. 
11. Shi XB, Pan HP, Xie W, Jiao XG, Fang $Y$, Chen $G$, et al. Three-way interactions between the tomato plant, Tomato yellow leaf curl virus, and the whitefly Bemisia tabaci facilitate virus spread. J Econ Entomol. 2014;107:920-6.

12. Shi XB, Pan HP, Zhang HY, Jiao XG, Xie W, Wu QJ, et al. Bemisia tabaci Q carrying Tomato yellow leaf curl virus strongly suppresses host plant defenses. Sci Rep. 2014:4:5230.

13. Pan HP, Chu D, Liu BM, Shi XB, Guo LT, Xie W, et al. Differential effects of an exotic plant virus on its two closely related vectors. Sci Rep. 2013;3:2230,

14. Mauck KE, De Moraes CM, Mescher MC. Deceptive chemical signals induced by a plant virus attract insect vectors to inferior hosts. Proc Natl Acad Sci U S A. 2010;107:3600-5.

15. Mauck KE, De Moraes CM, Mescher MC. Biochemical and physiological mechanisms underlying effects of Cucumber mosaic virus on host-plant traits that mediate transmission by aphid vectors. Plant Cell Environ. 2014:37:1427-39.

16. Mauck KE, Smyers E, De Moraes CM, Mescher MC. Virus infection influences host plant interactions with non-vector herbivores and predators. Funct Ecol. 2015;29:662-73.

17. Sisterson MS. Effects of insect-vector preference for healthy or infected plants on pathogen spread: insights from a model. J Econ Entomol. 2008;101:1-8.

18. Koornneef A, Pieterse CM. Cross talk in defense signaling. Plant Physiol. 2008;146:839-44

19. Ali JG, Agrawal AA. Specialist versus generalist insect herbivores and plant defense. Trends Plant Sci. 2012;17:293-302.

20. Abe H, Tateishi K, Seo S, Kugimiya S, Hirai MY, Sawada Y, et al. Disarming the jasmonate-dependent plant defense makes nonhost Arabidopsis plants accessible to the American serpentine leafminer. Plant Physiol. 2013;163: 1242-53.

21. Alazem M, Lin NS. Roles of plant hormones in the regulation of host-virus interactions. Mol Plant Pathol. 2015;16:529-40.

22. Robert-Seilaniantz A, Grant M, Jones JDG. Hormone crosstalk in plant disease and defense: more than just jasmonate salicylate antagonism. Annu Rev Phytopathol. 2011;49:317-43.

23. Thaler JS, Humphrey PT, Whiteman NK. Evolution of jasmonate and salicylate signal crosstalk. Trends Plant Sci. 2012;17:260-70.

24. Meldau S, Ullman-Zeunert L, Govind G, Bartram S, Baldwin IT. MAPKdependent JA and SA signalling in Nicotiana attenuata affects plant growth and fitness during competition with conspecifics. BMC Plant Biol. 2012;12:213.

25. Alba JM, Schimmel BC, Glas JJ, Ataide LM, Pappas ML, Villarroel CA, et al. Spider mites suppress tomato defenses downstream of jasmonate and salicylate independently of hormonal crosstalk. New Phytol. 2015;205:828-40.

26. Donovan MP, Nabity PD, Delucia EH. Salicylic acid-mediated reductions in yield in Nicotiana attenuate challenged by aphid herbivory. Arthropod-Plant Inte. 2013;7:45-52

27. Shi XB, Pan HP, Xie W, Wu QJ, Wang SL, Liu Y, et al. Plant virus differentially alters the plant's defense response to its closely related vectors. PLoS ONE. 2013;8:e83520.

28. Livne B, Faktor O, Zeitoune S, Edelbaum O, Sela I. TMV-induced expression of tobacco $\beta$-glucanase promoter activity is mediated by a single, inverted GCC motif. Plant Sci. 1997;130:159-69.

29. Chen HJ, Hou WC, Kuc J, Lin YH. Salicylic acid mediates alternative signal transduction pathways for pathogenesis-related acidic $\beta$-1, 3-glucanase (protein $\mathrm{N}$ ) induction in tobacco cell suspension culture. J Plant Physiol. 2002:159:331-7.

30. Turner JG, Ellis C, Devoto A. The jasmonate signal pathway. Plant Cell. 2002; 14:S153-64.

31. Zhang HY, Xie XZ, Xu YZ, Wu NH. Isolation and functional assessment of a tomato proteinase inhibitor II gene. Plant Physiol Bioch. 2004:42:437-44.

32. Zhu F, Xi DH, Yuan S, Xu F, Zhang DW, Lin HH. Salicylic acid and jasmonic acid are essential for systemic resistance against Tobacco mosaic virus in Nicotiana benthamiana. Mol Plant Microbe In. 2014:27:567-77.

33. Livak KJ, Schmittgen TD. Analysis of relative gene expression data using realtime quantitative $P C R$ and the 2- $\Delta \Delta C T$ method. Methods. 2001;25:402-8.

34. Abdollahi MR, Memari HR, van Wijnen AJ. Factor affecting the endogenous $\beta$-glucuronidase activity in rapeseed haploid cells: how to avoid interference with the Gus transgene in transformation studies. Gene. 2011 487:96-102.

35. Ziebell H, Murphy AM, Groen SC, Tungadi T, Westwood JH, Lewsey MG, et al. Cucumber mosaic virus and its $2 \mathrm{~b}$ RNA silencing suppressor modify plant-aphid interactions in tobacco. Sci Rep. 2011;1:187.
36. Spoel SH, Koornneef A, Claessens SM, Korzelius JP, Van Pelt JA, Mueller MJ, et al. NPR1 modulates cross-talk between salicylate- and jasmonatedependent defense pathways through a novel function in the cytosol. Plant Cell. 2003:15:760-70.

37. El Oirdi M, El Rahman TA, Rigano L, El Hadrami A, Rodriguez MC, Daayf F, et al. Botrytis cinerea manipulates the antagonistic effects between immune pathways to promote disease development in tomato. Plant Cell. 2011;23: 2405-21.

38. Lewsey MG, González I, Kalinina NO, Palukaitis P, Canto T, Carr JP. Symptom induction and RNA silencing suppression by the Cucumber mosaic virus $2 \mathrm{~b}$ protein. Plant Signal Behav. 2010;5:705-8.

39. Love AJ, Geri C, Laird J, Carr C, Yun B-W, Loake GJ, et al. Cauliflower mosaic virus protein $\mathrm{P} 6$ inhibits signaling responses to salicylic acid and regulates innate immunity. PLoS ONE. 2012;7, e47535.

40. Funnella DL, Lawrenceb CB, Pedersenc JF, Schardl CL. Expression of the tobacco b-1, 3-glucanase gene, PR-2d, following induction of SAR with Peronospora tabacina. Physiol Mol Plant P. 2004;65:285-96.

41. Pegadaraju V, Knepper C, Reese J, Shah J. Premature leaf senescence modulated by the Arabidopsis PHYTOALEXIN DEFICIENT4 gene is associated with defense against the phloem-feeding green peach aphid. Plant Physiol. 2005;139:1927-34

42. Avila CA, Arevalo-Soliz LM, Jia LL, Navarre DA, Chen Z, Howe GA, et al. Loss of function of FATTY ACID DESATURASE7 in tomato enhances basal aphid resistance in a salicylate-dependent manner. Plant Physiol. 2012;158:2028-41.

43. Braendle C, Davis GK, Brisson JA, Stern DL. Wing dimorphism in aphids. Heredity. 2006:97:192-9.

44. Müller CB, Williams IS, Hardie J. The role of nutrition, crowding and interspecific interactions in the development of winged aphids. Ecol Entomol. 2001;26:330-40.

45. Carmo-Sousa M, Moreno A, Garzo E, Fereres A. A non-persistently transmitted-virus induces a pull-push strategy in its aphid vector to optimize transmission and spread. Virus Res. 2014;186:38-46.

\section{Submit your next manuscript to BioMed Central and we will help you at every step:}

- We accept pre-submission inquiries

- Our selector tool helps you to find the most relevant journal

- We provide round the clock customer support

- Convenient online submission

- Thorough peer review

- Inclusion in PubMed and all major indexing services

- Maximum visibility for your research

Submit your manuscript at www.biomedcentral.com/submit 